\title{
REPRESENTASI HONNE DAN TATEMAE PADA TOKOH SAKURA DALAM MANGA “NARUTO” (ANALISIS PRAGMATIK)
}

\author{
G. A. D. P. Widiastuti ${ }^{1}$, N. N. Suartini ${ }^{2}$, K. E. K. Adnyani ${ }^{3}$ \\ 123 Jurusan Pendidikan Bahasa Jepang, Universitas Pendidikan Ganesha, Singaraja,Bali \\ e-mail: ayudyah515@gmail.com, nnsuartiniundiksha.ac.id, krishna.adnyani@undiksha.ac.id
}

\begin{abstract}
Abstrak
Penelitian ini menganalisis honne dan tatemae dari representasi budaya honne dan tatemae pada interaksi tokoh Sakura dengan tokoh lain dalam manga "Naruto" serta faktor-faktor yang memengaruhi penggunaan honne dan tatemae oleh tokoh Sakura. Penelitian ini menggunakan teori representasi dan teori pragmatik. Metode pengumpulan data dengan metode pustaka dan instrumen berupa kartu data. Data yang dikumpulkan kemudian dikelompokkan sesuai rumusan masalah lalu dianalisis menggunakan metode analisis deskriptif kualitatif. Hasil yang ditemukan yaitu representasi honne dan tatemae terlihat pada interaksi tokoh Sakura dengan tokoh lain dalam manga "Naruto". Ketika berinteraksi dengan orang yang memiliki hubungan dekat, pada situasi informal dan saat tujuan tuturnya tidak dapat tersampaikan dengan baik bila menggunakan tatemae, Sakura menggunakan honne. Tetapi pada situasi tutur tertentu Sakura tidak mengungkapkan seluruh pemikirannya di depan publik karena dikhawatirkan akan merusak keharmonisan hubungan apabila hal tersebut diungkapkan seluruhnya. Sedangkan ketika berbicara dengan orang yang lebih tua, orang yang baru dikenal, orang asing, orang yang memiliki jabatan dan status sosial yang lebih tinggi, Sakura menggunakan tatemae. Tatemae juga digunakan oleh Sakura pada situasi formal dan bila honne tidak sesuai dengan norma yang berlaku atau memiliki potensi merusak keharmonisan hubungan dan menyakiti lawan tutur. Faktor-faktor yang memengaruhi penggunaan honne dan tatemae yaitu situasi, hubungan dengan lawan tutur dan tujuan.
\end{abstract}

Kata kunci : representasi, honne, tatemae, manga "Naruto"

要旨

本研究は、サクラのキャラクターが「ナルト」漫画の他のキャラクターとやりとりしていると きに、本音と建前の文化を表現することによって、本音と建前の分析を論じて、サクラのキャ ラクターによる本音と建前の使用に影響を及ぼす要因について明らかにする。本研究は表現理 論と実用理論を用いている。使用されるデータは文学的方法であり、データカードの形で器具 を使用する。収集したデータは問題の定式化に従ってグループ化され、記述的定性分析法を使 用して分析される。その研究の結果、「ナルト」漫画ではサクラと他のキャラクターとの相互 作用に本音と建前の表現が見られる。サクラは次のことをするときに本音を使う。彼女と密接 な関係を持っている人とのやりとり、非公式な状況でのとき、建前の使用時に会話の目的を正 しく伝えることができないとき。しかし、特定の状況では、サクラは彼女の考えをすべて公開 していない。それが恐れるので、それが完全に開示されていれば、調和関係に損害を与える。 サクラは次のことをするときに建前を使う。高齢者と、より高い地位と社会的地位を持つ人、 新しい人と見知らぬ人と話すこと、本音が一般的な規範に従っていない場合、または関係の調 和に害を及ぼし特定の関係者に害を及ぼす可能性がある場合、正式な状態である。本音と建前 の使用に影響を与える要因は状況、他の人との関係、そして目的。

キーワード：表示、本音、建前、「ナルト」漫画

\section{Pendahuluan}

Komunikasi merupakan hal penting bagi setiap individu untuk bisa saling berhubungan. Melalui komunikasi, individu dapat saling bertukar informasi, opini dan hal lainnya. Komunikasi juga digunakan untuk memenuhi keinginan pribadi seperti keinginan untuk mengetahui sesuatu, keinginan untuk memiliki suatu benda, keinginan untuk 
mendapat pekerjaan dan keinginan lainnya. Karena itu komunikasi yang baik dan efektif sangat diperlukan agar segala keinginan dan hal yang dibutuhkan dapat terpenuhi dengan baik. Komunikasi dapat dikatakan efektif apabila makna yang diterima oleh penerima pesan sama dengan makna yang disampaikan oleh penyampai pesan. Jika suatu hal maknanya tidak dapat ditangkap dengan baik oleh penerima pesan karena tidak dikomunikasikan dengan baik, maka masalah pun dapat timbul sebagai dampaknya.

Komunikasi dan budaya memiliki hubungan yang erat. Menurut E.T. Hall (dalam Lubis, 2002) budaya adalah komunikasi dan komunikasi adalah budaya. Dalam hal ini budaya menjadi bagian dari komunikasi. Sedangkan komunikasi berperan dalam menentukan, memelihara, mengembangkan serta mewariskan budaya baik secara lisan maupun tulisan. Karena itu semakin mirip latar belakang sosial-budaya penyampai dan penerima pesan maka semakin efektif pula komunikasi yang terjadi. Sebagai contoh, ada orang Jepang yang datang berlibur ke Bali dan makan di sebuah restoran yang ia ketahui dari agen penjual paket perjalanan wisata di Jepang. Ketika ditanyai secara langsung oleh pihak restoran mengenai pendapatnya tentang makanan yang disajikan, orang Jepang itu mengatakan makanannya enak. Tapi kenyataannya, makanan yang tersisa di piringnya banyak. Lalu beberapa jam setelahnya ada laporan keluhan yang dikirimkan oleh agen penjual paket perjalanan wisata di Jepang tentang rasa makanan yang dijual di restoran tersebut.

Pada gambaran contoh kasus di atas, diketahui bahwa orang Jepang tidak jujur dalam mengungkapkan apa yang dirasakannya saat pihak restoran menanyakan mengenai makanan yang disajikan. la mengatakan hal yang berkebalikan dengan apa yang dirasakannya dan melaporkan keluhannya pada agen penjual paket perjalanan wisata di Jepang. Bukan pada pihak restorannya secara langsung. Hal semacam ini dapat menimbulkan kesalahpahaman dan dapat membuat pihak restoran memandang buruk citra orang Jepang apabila pihak restoran tidak mengetahui budaya orang Jepang dalam berkomunikasi.

Orang Jepang dikenal sangat mementingkan keharmonisan hubungan dengan orangorang disekitarnya dan memiliki standar yang digunakan untuk menentukan sikap. Standar tersebut yaitu konsep uchi-soto. Uchi dalam bahasa Jepang berarti 'rumah'. Sesuai dengan artinya, makna uchi dalam pergaulan orang Jepang berarti internal atau 'orang dalam'. Sedangkan soto berarti eksternal atau 'orang luar' (Wiyatasari, 2017). Orang dalam yang dimaksud dalam uchi biasanya merupakan orang-orang terdekat seperti keluarga dan sahabat karib. Sementara itu yang lainnya digolongkan pada lingkup soto. Konsep uchi-soto ini menyebabkan adanya dikotomi pada beberapa budaya orang Jepang. Salah satunya yaitu budaya honne dan tatemae. Budaya yang digunakan oleh orang Jepang dalam berkomunikasi.

Honne adalah perasaan yang sebenarnya sedangkan tatemae adalah perasaan yang berbeda dengan perasaan yang sebenarnya (Gakken, 2002). Dalam kaitannya dengan konsep uchi-soto, honne adalah perasaan yang biasanya ditunjukkan pada lingkup uchi sedangkan tatemae adalah perasaan yang biasanya ditunjukkan pada lingkup soto. Karena itu orang Jepang biasanya akan menampilkan tatemae di depan publik dan menyembunyikan honne.

Budaya honne dan tatemae mirip dengan budaya sopan santun di Indonesia. Kedua budaya tersebut memiliki tujuan yang sama yaitu untuk menciptakan keharmonisan dan keselarasan hubungan. Tetapi penerapan budaya sopan santun oleh orang Indonesia berbeda dengan penerapan budaya honne dan tatemae oleh orang Jepang. Karena itu honne dan tatemae dipilih menjadi hal yang diteliti dalam penelitian ini. Tujuannya adalah agar masyarakat Indonesia, khususnya bagi pembelajar bahasa dan budaya Jepang serta orang yang hidupnya berhubungan dengan orang Jepang bisa lebih memahami budaya ini. Supaya kelak jika berkomunikasi dengan orang Jepang komunikasi yang terjadi dapat berjalan dengan baik.

Untuk mengetahui honne dan tatemae, manga (komik Jepang) dipilih sebagai media penelitian. Ini karena mangaka (komikus) pada umumnya membuat karakter dalam manga sesuai dengan karakteristik orang Jepang sehingga manga dapat dikatakan sebagai salah satu hal yang merepresentasikan orang Jepang. Selain itu, perpaduan antara gambar dan 
balon (area pada halaman komik untuk menuliskan ujaran tokoh) yang berisi percakapan pada manga mampu menggambarkan suasana yang terjadi pada suatu interaksi antar tokoh. Gambar yang ditampilkan dan onomatopoeia yang biasanya ditulis diluar balon pun dapat membantu memperjelas konteks. Dengan kelebihan tersebut, manga dapat digunakan untuk memudahkan dalam membedakan honne dan tatemae. Karena itu manga dipilih sebagai media penelitian.

Manga yang digunakan sebagai media penelitian yaitu manga "Naruto" karya Kishimoto Masashi. Alasannya karena di dalam manga ini terdapat tokoh yang digambarkan memiliki inner (gambaran batin) pada situasi tertentu. Tokoh tersebut adalah Haruno Sakura. Adanya gambaran inner Sakura ini dapat memudahkan dalam membedakan tuturan dan sikap tokoh yang menunjukkan honne dan tatemae. Sehingga tokoh ini dipilih sebagai subjek penelitian. Objek yang diteliti yaitu tuturan dan sikap Sakura yang menggambarkan honne dan tatemae saat Sakura berinteraksi dengan tokoh lain yang ada pada manga "Naruto".

\section{Pragmatik}

Pragmatik berhubungan dengan studi tentang makna yang disampaikan oleh pembicara atau penulis dan diinterpretasikan oleh pendengar atau pembaca. Pragmatik berfokus pada analisis tentang hal yang dimaksud oleh seseorang melalui ujaran yang dilakukan daripada arti kata atau frase dari ujaran tersebut. Pragmatik juga melibatkan interpretasi mengenai maksud ujaran dalam suatu konteks tertentu dan bagaimana suatu keadaan memengaruhi ujaran yang dilakukan oleh seseorang. Selain itu, pragmatik menggali hal yang tidak dikatakan menjadi dapat diketahui dan menganggap hal tersebut sebagai bagian dari komunikasi. Karena itu pragmatik dapat dikatakan sebagai studi tentang makna pembicara, makna kontekstual, dan studi tentang hal yang dikomunikasikan melebihi hal yang dikatakan (Yule, 1996).

Pragmatik melihat hubungan tanda dengan penggunanya. Dalam pragmatik, tanda terlihat dalam dua bentuk, yaitu verbal (ujaran) dan non verbal (gesture). Selain itu pragmatik melihat latar belakang dari ujaran dan gesture tersebut. Pada suatu ujaran, tindakan akan terjadi sebagai reaksi atas ujaran tersebut dan tergantung pada konteks yang berlaku. Lalu bentuk ujarannya ikut memengaruhi dalam menginterpretasikan ujaran tersebut (Nitiasih dan Hermawan, 2013).

Dalam menganalisis ujaran, yang harus diperhatikan yaitu tanda dalam semiotik yang berupa kata, kosakata, ataupun frasa. Latar belakang yang memengaruhi timbulnya ujaran pun dapat berperan dalam memberikan referensi. Dell Hymes (dalam Nitiasih dan Hermawan, 2013:190-192) menyatakan konsep komponen tutur adalah sebagai berikut.

1. S (setting and scene) mengacu pada tempat dan waktu terjadinya sebuah tuturan, lalu suasana tutur mengacu pada faktor psikologis dan batasan kultural dari tempat terjadinya tuturan.

2. $\mathrm{P}$ (participants) mengacu pada minimal dua pihak dalam bertutur (penutur dan mitra tutur). Komponen ini melibatkan dua dimensi sosial manusia, yakni dimensi horizontal yang menyangkut hubungan penutur dengan mitra tutur yang telah terbangun sebelumnya dan dimensi vertikal yang berkaitan dengan masalah umur, kedudukan, status sosial dari para peserta tutur.

3. E (ends) mengacu pada tujuan dari peristiwa tutur.

4. A (act sequence) mengacu pada pokok tuturan yang selalu berubah, dimana perubahan ini akan memengaruhi pemilihan kode dalam bertutur.

5. K (key) mengacu pada nada, cara dan motivasi di mana suatu tindakan dapat dilakukan dalam bertutur, dimana nada ini dapat menunjukkan nada santai, serius, tegang, dan lain sebagainya pada tuturan.

6. I (instrumentalities) mengacu pada sarana tutur yang menunjuk kepada saluran tutur dan bentuk tutur. Saluran tutur adalah alat dimana itu dapat dimunculkan oleh penutur dan sampai kepada mitra tutur. Bentuk tutur dapat berupa bahasa dan variasi-variasi bahasa yang banyak ditentukan oleh saluran tutur. 
7. $\mathrm{N}$ (norms) mengacu pada dua hal, yakni norma interaksi dan norma interpretasi. Norma interaksi menunjuk kepada dapat atau tidaknya sesuatu dilakukan oleh seseorang dalam bertutur dengan mitra tutur, norma interpretasi memungkinkan pihak-pihak yang terlibat dalam komunikasi untuk memberikan interpretasi kepada mitra tutur, khususnya jika yang terlibat dalam komunikasi adalah warga dari komunitas tutur yang berbeda.

8. G (genres) yang mengacu kepada jenis kategori kebahasaan yang sedang dituturkan. Jenis tuturan ini akan berhubungan dengan kategori wacana seperti percakapan, cerita, pidato, atau lainnya.

Dari pemaparan di atas, dapat diketahui bahwa konsep komponen tutur yang telah dipaparkan itulah yang menjadi referensi dalam menginterpretasikan suatu tanda. Data yang telah diinterpretasi selanjutnya dikelompokkan pada kategori tertentu sebelum dianalisis sesuai dengan tujuan yang ingin dicapai.

\section{Representasi}

Menurut Hall (1977), bahasa memiliki fungsi sebagai sistem representasikarena dalam bahasa kita menggunakan tanda-tanda, baik dalam bentuk suara, kata-kata tertulis, gambar, musik dan lain sebagainya. Tujuannya yaitu untuk menunjukkan atau menggambarkan kepada orang lain mengenai konsep, ide ataupun perasaan yang dimiliki terhadap sesuatu. Teori Hall (1977) memperlihatkan suatu proses yaitu 'arti' diproduksi dengan menggunakan bahasa dan dipertukarkan oleh antar anggota kelompok dalam sebuah kebudayaan. Representasi menghubungkan antara konsep dalam benak kita dengan menggunakan bahasa yang memungkinkan kita untuk mengartikan benda, orang, kejadian yang nyata, dan dunia imajinasi dari objek, orang,benda, dan kejadian yang tidak nyata. Contohnya seperti pada fotografi, pameran, musik, dan pertandingan sepakbola.

Fotografi disebut sebagai sistem representasi karena foto yang dihasilkan dapat mengomunikasikan makna dari fotografi tersebut. Pameran dapat dikatakan sebagai 'bahasa' karena menggunakan objek-objek pada tampilan pamerannya untuk menghasilkan makna tertentu tentang subjek yang dipamerkan. Musik dianggap sebagai 'bahasa' karena dapat mengomunikasikan perasaan serta ide-ide tentang suatu hal. Dalam pertandingan sepak bola yaitu adanya pendukung yang membawa spanduk dan slogan. Wajah dan tubuh mereka biasanya dicat dengan warna tertentu atau ditulis dengan lambang tertentu untuk menyampaikan dukungannya pada suatu kelompok. Semua itu terjadi karena merupakan praktik simbolik yang memberikan makna. Hal tersebut juga dilakukan untuk mengekspresikan sesuatu berdasarkan kebudayaannya atau menyesuaikan dengan kebudayaan masyarakat lain (Hall, 1977).

Melalui representasi, suatu makna diproduksi dan dipertukarkan antar anggota masyarakat. Jadi dapat dikatakan bahwa representasi secara singkat adalah salah satu cara untuk memproduksi makna. Representasi bekerja melalui sistem representasi yang terdiri dari dua komponen penting, yakni konsep dalam pikiran dan bahasa. Kedua komponen ini saling berhubungan. Konsep dari suatu hal yang dimiliki dan ada dalam pikiran membuat manusia mengetahui makna dari suatu hal tersebut. Makna tidak akan dapat dikomunikasikan jika seseorang tidak dapat mengungkapkannya dalam bahasa yang dapat dimengerti oleh manusia lainnya. Sehingga dapat disimpulkan bahwa representasi adalah suatu proses untuk memproduksi makna dari konsep yang ada dipikiran kita melalui bahasa. Namun proses permaknaannya tergantung pada latar belakang pengetahuan dan pemahaman suatu kelompok sosial terhadap suatu tanda. Suatu kelompok harus memiliki pengalaman yang sama untuk dapat memaknai sesuatu yang nyaris sama.

\section{Honne dan Tatemae}

Setiap kelompok masyarakat memiliki budaya yang berbeda dengan kelompok masyarakat lainnya (Koentjaraningrat, 1979) sehingga setiap kelompok masyarakat memiliki ciri khas tertentu yang membedakannya dengan kelompok masyarakat lain. Karena itu dalam berinteraksi dengan orang Jepang kemampuan berbicara yang fasih saja tidak cukup. Pemahaman mengenai budaya Jepang penting dilakukan agar tidak kesulitan dalam menangkap makna dan tidak tersinggung dengan sikap orang Jepang ketika berinteraksi. 
Budaya orang Jepang dalam berinteraksi dengan orang-orang disekitarnya menggunakan konsep honne dan tatemae yang membedakan antara penampilan resmi dengan realitas yang tersembunyi. Perbedaan ini sering diharapkan untuk diperlihatkan yaitu yang secara normatif tepat dan benar, dan aktualitasnya mungkin tidak dapat diterima oleh publik (hanya diketahui secara pribadi atau oleh orang-orang terdekat saja) (Sugimoto, 2009). Kedua aspek tersebut membingungkan sehingga harus memberikan perhatian khusus untuk mengetahui makna sesungguhnya yang ingin disampaikan.

Dalam artikel yang ditulis oleh Naito dan Gielen (1992:5), Sugiyama-Lebra (1976) menyatakan tentang konsep singkat dari honne dan tatemae.

Honne berarti alami, nyata, atau keinginan dan kecenderungan batin, sedangkan

'Tatemae' mengacu pada standar, prinsip, atau aturan yang mengikat secara lahiriah.

Pada dasar perbedaannya, orang Jepang berpikir bahwa "orang dewasa" haruslah memahami dua sisi orang lain dan mengekspresikan sisi yang relevan pada suatu situasi".

Honne adalah pemikiran ataupun perasaan yang sebenarnya (sisi dalam) sedangkan tatemae adalah pemikiran ataupun perasaan lain diluar perasaan yang sebenarnya yang diperlihatkan di depan publik (sisi luar) yang berubah-ubah sesuai dengan kondisi ataupun situasi yang sedang dihadapi (Fujino, 2010).

Honne mengacu pada perasaan dan keinginan yang tidak dapat ditunjukkan secara langsung. Jika tatemae sesuai dengan aturan atau norma yang berlaku, maka honne akan disembunyikan atau disamarkan untuk menghindari kerusakan pada keharmonisan hubungan. Namun dalam keseharian, bukan berarti honne nyaris tidak diperlihatkan sama sekali. Honne biasanya diperlihatkan atau diutarakan pada orang-orang yang memiliki hubungan sangat akrab, contohnya seperti anggota keluarga, teman dekat atau sahabat karib. Honne juga bisa diperlihatkan pada waktu santai (situasi informal). Contohnya seperti pada saat pekerja kantor mengadakan pesta yang bersifat intern (hanya orang-orang yang tergabung dalam kelompok itu saja yang terlibat di dalamnya). Atau mengajak satu sama lain makan atau minum bersama di suatu tempat setelah jam kantor berakhir (Mickova, 2003; Sugimoto, 2009).

Tatemae mengacu pada aturan yang dibuat, yang belum tentu diterima atau dilakukan oleh pihak-pihak yang terlibat (tidak dilakukan berdasarkan keinginan). Sehingga pada umumnya tatemae digunakan sebagai public morality yang membuat individu menyembunyikan atau menyamarkan honne. Namun tatemae tidak hanya dilakukan untuk formalitas saja. Terkadang orang Jepang juga melakukan tatemae untuk honne yang mereka sembunyikan demi kepentingan pribadi atau mencari keuntungan. Misalnya saat ingin mendapatkan jabatan yang lebih tinggi di tempat kerja, seseorang akan berdedikasi, bertutur dan bersikap sesuai dengan ketentuan perusahaan. Dalam konteks tersebut, keinginan untuk mendapatkan jabatan yang lebih tinggi adalah honne, sedangkan perilaku berdedikasi, bertutur, dan bersikap sesuai dengan ketentuan perusahaan adalah tatemae (Shimizu, 2000; Sugimoto, 2009).

Dari pengertian diatas, dapat disimpulkan bahwa honne selalu berada dibelakang tatemae. Karena itu penting untuk mengetahui honne dan tatemae. Agar saat berinteraksi dengan orang Jepang kita dapat memahami makna dan maksud yang ingin disampaikan kepada kita dengan baik sekaligus untuk menghindari kesalahpahaman.

\section{Metode}

Pendekatan dan jenis penelitian ini adalah deskriptif kualitatif. Jenis data dalam penelitian ini yaitu data kualitatif yang disajikan dalam bentuk narasi dan uraian. Sumber data penelitian ini diperoleh dari pengumpulan data hasil pengamatan sikap dan tuturan tokoh Sakura ketika berinteraksi dengan tokoh lain dalam manga "Naruto". Pengumpulan data dilakukan dengan menggunakan metode pustaka dan menggunakan instrumen berupa kartu data. Data yang dikumpulkan yaitu percakapan antara Sakura dengan tokoh lain dan potongan adegan saat percakapan tersebut berlangsung. Data kemudian diklasifikasikan 
berdasarkan honne dan tatemae. Setelah itu data yang telah diklasifikasikan tersebut dianalisis sesuai dengan rumusan masalah lalu disimpulkan.

\section{Hasil dan Pembahasan}

Berdasarkan permasalahan, teori, metode serta data yang terkumpul, hasil yang didapat dari penelitian ini adalah sebagai berikut.

\section{Representasi Honne dan Tatemae}

Dari penelitian yang telah dilakukan, representasi honne dan tatemae terlihat pada saat tokoh Sakura berinteraksi dengan tokoh lain dalam manga "Naruto". Sakura menggunakan honne ketika Sakura berinteraksi dengan tokoh yang memiliki hubungan dekat dengannya, sedang berada pada situasi informal, serta ketika Sakura memiliki tujuan yang tidak bisa dicapai bila menggunakan tatemae. Tetapi pada situasi tertentu Sakura hanya mengungkapkan sebagian pemikirannya karena dikhawatirkan akan merusak keharmonisan hubungan apabila Sakura mengungkapkan seluruh pemikirannya kepada lawan tutur. Sedangkan untuk tatemae, Sakura menggunakannya ketika Sakura sedang berada pada situasi formal dan ketika Sakura terlibat pembicaraan dengan orang yang lebih tua, memiliki jabatan dan status sosial yang lebih tinggi, orang yang baru dikenal dan orang asing.

\section{Representasi Penggunaan Honne oleh Tokoh Sakura dalam Manga "Naruto"}

(Seri 3, halaman 15)

\section{Situasi :}

Tim 7 melakukan latihan yang diinstruksikan oleh Kakashi yaitu latihan memanjat pohon dengan hanya menggunakan kaki. Diantara 3 anggota yang ada, Sakura adalah anggota pertama yang berhasil memanjat pohon seperti yang telah diajarkan Kakashi pada tim 7 . Kakashi yang bangga dengan pencapaian yang diraih oleh Sakura memuji Sakura. Namun pujian Kakashi untuk Sakura yang selanjutnya adalah membandingkan keberhasilan Sakura dengan kemampuan Naruto dan Sasuke.

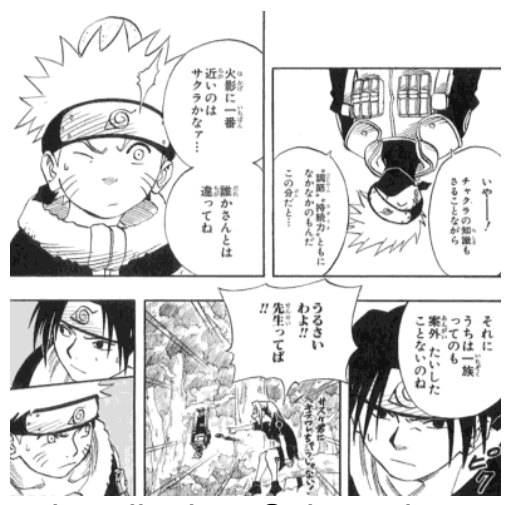

\section{Percakapan :}

Gambar 1. Kakashi Membandingkan Sakura dengan Naruto dan Sasuke

Kakashi

: 火影に一番近いのはサク

ラかなー...

Hokage ni ichiban chikai no wa Sakura ka na ...

Kalau begini yang kemampuannya paling dekat dengan Hokage ternyata

Sakura ya...

誰かさんとは違ってね

Dare ka san to wa chigatte ne

Berbeda sekali dengan seseorang disini

それにうちは一族ってのも案外たいしたことないのね

Sore ni Uchiha ichizoku tte no mo angaitai shita koto nai no ne

Selain itu, yang namanya klan Uchiha itu diluar dugaan, tak begitu hebat ya

Sakura

ば!!

Urusai wa yo!! Sensei tte ba!! 
Guru!! Berisik tahu!!

Inner Sakura : サスケ君にキラワレちゃ

うじゃない!!

Sasuke-kun ni kiraware chau janai!!

Aku 'kan jadi dibenci Sasuke!!

Analisis :

(Sumber terjemahan : Naruto Vol 3 (bahasa Indonesia))

Pada percakapan di atas dapat diketahui bahwa Kakashi memuji keberhasilan Sakura dan membandingkan kemampuan Sakura dengan kemampuan Naruto dan Sasuke. Namun Sakura tidak bangga dengan pujian yang diberikan oleh Kakashi terhadap dirinya. Justru sebaliknya, Sakura malah merasa kesal karena Kakashi telah merendahkan orang yang disukainya yaitu Sasuke dengan menggunakan dirinya. Sakura takut kalau Sasuke akan membencinya. Hal tersebut terlihat dari ucapan Sakura terhadap Kakashi yaitu "Guru!! Berisik tahu!!" yang diucapkan oleh Sakura dengan ekspresi kesal serta gestur tangan yang menunjuk Kakashi secara langsung.

Sikap dan tuturan Sakura terhadap Kakashi menunjukkan bahwa Sakura menggunakan honne. Ini karena Sakura bersikap dan bertutur sesuai dengan perasaannya yang sebenarnya. Hal tersebut diperkuat dengan inner Sakura yang juga mengucapkan "Aku 'kan jadi dibenci Sasuke!!" sebagai kelanjutan dari kalimat yang Sakura tuturkan dihadapan Kakashi.

Hal yang dilakukan oleh Sakura tersebut sebenarnya termasuk hal yang tidak sopan karena Kakashi adalah guru pembimbing timnya dan berumur lebih tua darinya. Sakura berani melakukannya karena Kakashi adalah orang yang santai dan selalu bisa menerima kritik dan saran dari orang-orang disekitarnya.

\section{Representasi Penggunaan Tatemae oleh Tokoh Sakura dalam Manga "Naruto"} (Seri 1, halaman 112)

Situasi :

Naruto membuat jebakan untuk pembimbing timnya dengan meletakkan penghapus papan yang masih dipenuhi oleh bubuk kapur di atas pintu kelas yang ia, Sasuke dan Sakura tempati. Naruto melakukannya karena pembimbingnya itu tak kunjung datang. la merasa sangat kesal karena hanya pembimbing timnya saja yang belum datang. Sindiran Sakura atas ulahnya bahkan tidak didengarkan olehnya. Hingga akhirnya pembimbing mereka datang dan terkena jebakan Naruto.

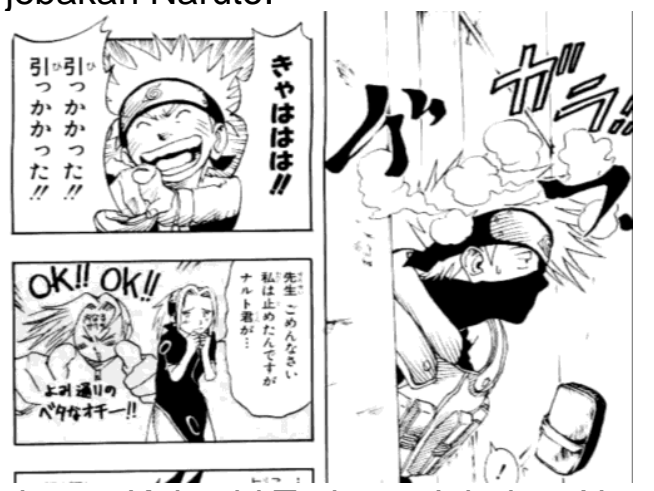

Percakapan :

Gambar 2. Kakashi Terkena Jebakan Naruto

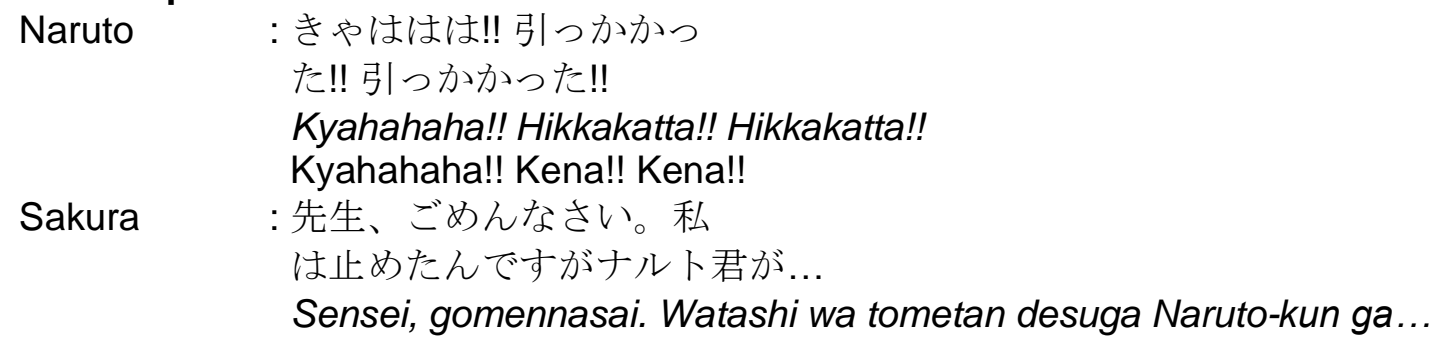


Guru, maaf. Aku sudah mencoba untuk menghentikannya, tapi Naruto...

Inner Sakura : OK!! OK!! よみ通りのべ

タなオキー!!

OK!! OK!! Yomi doori no betana oki!!

Yes!! Yes!! Itu lebih baik dari yang kubayangkan!!

(Sumber terjemahan : Naruto Vol 1 (bahasa Indonesia))

Analisis :

Pada percakapan di atas serta gambar 2 dapat diketahui bahwa Naruto tertawa saat pembimbing timnya yang bernama Hatake Kakashi terkena jebakan yang ia buat. Sakura yang melihat hal tersebut meminta maaf pada Kakashi dan berkata "Aku sudah mencoba untuk menghentikannya, tapi Naruto..." yang menunjukkan bahwa dia merasa menyesal atas kejadian yang menimpa Kakashi. Namun sisi lain Sakura menampilkan hal yang berbeda. Inner Sakura menampilkan wajah puas sambil mengacungkan kedua jempol tangannya sambil berkata "Yes!! Yes!! Itu lebih baik dari yang kubayangkan!!".

Perbedaan sikap dan tuturan Sakura dengan innemya menunjukkan bahwa Sakura menggunakan tatemae saat berbicara dengan Kakashi. Ini karena umur Kakashi lebih tua dari Sakura. Kakashi juga merupakan pembimbing timnya. Selain itu, Sakura baru pertama kali bertemu dengan Kakashi. Akan sangat tidak sopan apabila Sakura ikut tertawa seperti Naruto. Melakukan hal yang sama dengan yang dilakukan oleh Naruto tentu akan merusak citra dirinya baik dihadapan Kakashi maupun Sasuke. Karena itu Sakura bersikap berkebalikan dengan perasaannya yang sebenarnya.

Faktor-Faktor yang Memengaruhi Penggunaan Honne dan Tatemae dalam Komunikasi Honne dan tatemae tidak serta merta digunakan begitu saja oleh tokoh Sakura ketika berinteraksi dengan tokoh lain dalam manga Naruto. Penggunaannya didasari oleh beberapa hal. Dari hasil penelitian rumusan masalah pertama, didapatkan 3 faktor yang memengaruhi penggunaan honne dan tatemae oleh tokoh Sakura. Ketiga faktor tersebut sesuai dengan 3 dari 8 komponen tutur yang dikemukakan oleh Dell Hymes (dalam Nitiasih dan Hermawan, 2013:190-192). Ketiga faktor tersebut yaitu situasi, hubungan dengan lawan tutur dan tujuan yang akan dipaparkan sebagai berikut.

1. Situasi Tutur

Keadaan yang dimaksud pada faktor ini yaitu tempat, suasana dan waktu terjadinya tuturan. Faktor ini sesuai dengan komponen tutur Dell Hymes yaitu setting and scene. Komponen yang mengacu pada tempat dan waktu terjadinya sebuah tuturan juga suasana tutur yang mengacu pada faktor psikologis dan batasan kultural dari tempat terjadinya tuturan. Tuturan yang dilakukan disesuaikan dengan tempat, waktu dan suasana tutur. Bila berada pada situasi formal, tuturan hendaknya dilakukan secara formal. Sedangkan bila berada pada situasi yang lebih santai, tuturan dapat dilakukan secara informal.

Penggunaan honne dan tatemae dipengaruhi oleh komponen ini. Honne biasanya akan digunakan pada situasi informal, sedangkan tatemae biasanya digunakan pada situasi formal. Tetapi penggunaan honne dan tatemae pada suatu keadaan tidak selalu seperti itu. Honne terkadang digunakan pada situasi yang seharusnya dilakukan secara formal. Tatemae pun terkadang digunakan pada situasi yang sebenarnya bisa dilakukan secara informal.

2. Hubungan dengan Lawan Tutur

Faktor ini mengacu pada hubungan antara penutur dengan lawan tutur. Faktor ini sesuai dengan komponen tutur Dell Hymes yaitu participants. Komponen ini mengacu pada pihak yang bertutur (penutur dan mitra tutur) dan melibatkan dua dimensi sosial yaitu dimensi horizontal dan dimensi vertikal. Dimensi horizontal adalah hal yang menyangkut hubungan penutur dengan mitra tutur yang telah dibangun sebelumnya. Sedangkan dimensi vertikal adalah hal yang berkaitan dengan umur, kedudukan dan status sosial dari peserta tutur.

Hubungan peserta tutur menentukan penggunaan honne dan tatemae. Pada umumnya orang Jepang akan menggunakan tatemae pada orang-orang yang memiliki usia lebih tua atau memiliki jabatan dan status sosial yang lebih tinggi. Ini karena orang Jepang menghormati orang yang lebih tua dan orang yang memiliki jabatan dan status sosial yang 
lebih tinggi. Orang Jepang juga akan menggunakan tatemae pada orang asing dan orang yang baru dikenal. Sebaliknya honne digunakan pada orang-orang dekat. Contohnya seperti anggota keluarga dan sahabat karib (Sugimoto, 2009).

3. Tujuan Tuturan

Faktor ini mengacu pada tujuan dari peristiwa tutur dan sesuai dengan komponen tutur ends Dell Hymes. Tujuan dapat memengaruhi penutur dalam menggunakan budaya honne dan tatemae. Misalnya saat ingin mendapatkan jabatan yang lebih tinggi di tempat kerja, seorang pegawai akan berdedikasi, bertutur dan bersikap sesuai dengan ketentuan perusahaan. Dalam konteks tersebut keinginan pegawai untuk mendapatkan jabatan yang lebih tinggi adalah honne, sedangkan perilaku pegawai yaitu berdedikasi, bertutur, dan bersikap sesuai dengan ketentuan perusahaan adalah tatemae (Sugimoto, 2009). Tetapi tidak semua tujuan bisa dicapai dengan menggunakan tatemae. Ada juga hal-hal yang dapat dicapai dengan menggunakan honne.

\section{Simpulan dan Saran}

Berdasarkan hasil penelitian yang dilakukan mengenai honne dan tatemae pada tokoh Sakura saat berinteraksi dengan tokoh lain dalam manga "Naruto", dapat ditarik kesimpulan sebagai berikut.

Pertama, representasi budaya honne dan tatemae terlihat saat Sakura berinteraksi dengan tokoh lain dalam manga "Naruto". Sakura menggunakan honne ketika Sakura berinteraksi dengan tokoh yang memiliki hubungan dekat dengannya, saat sedang berada pada situasi informal, serta ketika Sakura memiliki tujuan yang tidak bisa dicapai bila menggunakan tatemae. Tetapi ketika Sakura menggunakan honne, ada kalanya Sakura hanya mengungkapkan sebagian pemikirannya pada lawan tutur. Ini karena Sakura tidak ingin merusak hubungannya dengan lawan tutur apabila Sakura mengungkapkan seluruh pemikirannya. Sedangkan untuk tatemae, Sakura menggunakannya ketika Sakura sedang berada pada situasi formal dan ketika Sakura terlibat pembicaraan dengan orang yang lebih tua, memiliki jabatan dan status sosial yang lebih tinggi, orang yang baru dikenal dan orang asing.

Kedua, faktor-faktor yang memengaruhi penggunaan honne dan tatemae oleh tokoh Sakura ketika berinteraksi dengan tokoh lain dalam manga Naruto didasari oleh beberapa hal. Dari hasil penelitian rumusan masalah pertama, didapatkan 3 faktor penggunaan honne dan tatemae oleh tokoh Sakura yang sesuai dengan 3 dari 8 komponen tutur yang dikemukakan oleh Dell Hymes. Ketiga faktor tersebut yaitu situasi, hubungan dengan lawan tutur dan tujuan.

Pada penelitian ini sikap dan tuturan yang mengandung honne dan tatemae dapat dengan mudah dibedakan karena menggunakan tokoh Sakura yang innemya digambarkan oleh mangaka (komikus) manga "Naruto" pada situasi tutur tertentu. Sehingga perbedaan antara hal yang ditunjukkan oleh Sakura di depan publik dengan hal yang disimpannya dalam hati terlihat dengan jelas. Tetapi pada kehidupan nyata honne dan tatemae sulit dibedakan. Karena itu untuk masyarakat, khususnya untuk pembelajar bahasa dan budaya Jepang serta orang yang hidupnya berhubungan dengan orang Jepang, disarankan agar berhati-hati dalam memaknai sikap dan tuturan orang Jepang. Supaya ketika berinteraksi dengan orang Jepang tidak terjadi kesalahpahaman dan komunikasi dapat berjalan dengan lancar dan harmonis.

\section{Daftar Pustaka}

Fujino, Gary. 2010. "“Glocal” Japanese Self-Identity: A Missiological Perspective on Paradigmatics Shifts in Urban Tokyo". International Journal of Frontier Missiology, Vol 24 No 7 Winter (hlm. 171-182).

Gakken. 2002. JAPAN AS IT IS. Fourth Edition. Tokyo: Gakken. 
Hall, Stuart. 1997. "The Work of Representation" Representation: Cultural Representations and Signifying Practices. London: Sage Publications.

Kishimoto, Masashi. 1999. Naruto (Vol 1). Tokyo: Shuiesha Inc

Kishimoto, Masashi. 1999. Naruto (Vol 3). Tokyo: Shuiesha Inc

Kishimoto, Masashi. 2004. Naruto (Vol 1, terjemahan Bahasa Indonesia). Jakarta: Elex Media Komputindo

Kishimoto, Masashi. 2004. Naruto (Vol 3, terjemahan Bahasa Indonesia). Jakarta: Elex Media Komputindo

Koentjaraningrat. 1979. Manusia dan Kebudayaan di Indonesia. Jakarta: Djambatan.

Lubis, Lusiana Andriani. 2002. Komunikasi Antar Budaya. Medan: Fakultas IImu Sosial dan IImu Politik, Universitas Sumatera Utara.

Mickova, Lubica. 2003. "The Japanese Indirectness Phenomenon". Asian and African Studies, Vol 12, No 2 (hlm. 135-147).

Naito, T. dan Gielen, U. 1992. "Tatemae and Honne: A Study of Moral Relativism in Japanese Culture".

Nitiasih, Putu Kerti dan Gede Satya Hermawan. 2013. Semiotika (Apa dan Bagaimana?). Singaraja: Fakultas Bahasa dan Seni Universitas Pendidikan Ganesha Singaraja.

Shimizu, Hidetada. 2000. "Japanese Cultural Psychology and Empathic Understanding : Implications for Academic and Cultural Psychology”. Ethos, Volume 28, No 2 (hlm. 224-247).

Sugimoto, Yoshio. 2009. An Introduction to Japanese Society. Third Edition. New York: Cambridge University Press.

Wiyatasari, Reny. 2017. "Representasi Konsep Uchi-Soto dalam Bahasa Jepang". Kiryoku, Volume 1, No 4 (hlm. 37-47).

Yule, George. 1996. Pragmatics. Oxford: Oxford University Press. 